\title{
EVALUASI SETTING RELE PROTEKSI UNTUK MENGURANGI BUSUR API PADA SWITCHGEAR DI BEKASAP AREA PT. CHEVRON PACIFIC INDONESIA
}

\author{
Doni Mahendra ${ }^{1}$, Arlenny ${ }^{2}$, Usaha Situmeang ${ }^{3}$ \\ Program Studi Teknik Elektro, Fakultas Teknik, Universitas LancangKuning \\ Jl. Yos Sudarso Km. 8 Rumbai, Pekanbaru, Telp. (0761) 52324 \\ Email: dony.mahendra @gmail.com, arlenny@unilak.ac.id, usahasitumeang @unilak.ac.id
}

\begin{abstract}
ABSTRAK
Sistem proteksi tenaga listrik harus mampu bekerja sesuai dengan tujuan serta fungsi yang ditentukan terhadap jenis gangguan yang terjadi. Salah satu gangguan yang terjadi adalah arus hubung singkat (short circuit) yang diikuti pelepasan energi panas dalam bentuk busur (arc flash) yang dapat merusak peralatan. Besar energi busur api yang dihasilkan tergantung dari waktu kerja sistem pengaman akibat gangguan arus hubung singkat. Semakin cepat rele pengaman bekerja, maka semakin kecil pula busur api yang dihasilkan dan begitu pula sebaliknya. Evaluasi setting rele proteksi di switchgear adalah mengubah setting time dial pada OCR primary dan OCR secondary. Untuk OCR primary nilai setting time dial sebelum nya 2,6 s menjadi 1,08 s sedangkan untuk OCR secondary dengan time dial 2,4 s menjadi 1,02 s. Perubahan setting pada OCR ini dihasilkan waktu kerja rele proteksi yang lebih cepat yaitu sebesar $0.208 \mathrm{~s}$. Dengan waktu kerja proteksi yang semakin cepat, nilai energi panas yang di hasilkan juga lebih kecil. Energi insiden yang di hasilkan adalah $2,59 \mathrm{cal} / \mathrm{cm}^{2}$ menjadi $1.48 \mathrm{cal} / \mathrm{cm}^{2}$.
\end{abstract}

\section{ABSTRACT}

Electric power protection systems must be able to work in accordance with the objectives and functions that are determined for the type of interference that occurs. One of the disturbances that occur is a short circuit which is followed by the release of heat energy in the form of an arc that can damage the equipment.The amount of arc energy generated depends on the working time of the safety system due to a short circuit current. The faster the safety relay works, the smaller the arc produced and vice versa. Evaluation of protection relay settings in switchgear is changing the time dial setting on OCR primary and secondary OCR. For primary OCR the time dial setting value is $2.6 \mathrm{~s}$ to $1.08 \mathrm{~s}$ while for secondary OCR the time dial is $2.4 \mathrm{~s}$ to $1.02 \mathrm{~s}$.Changes to the settings on this OCR are generated faster protection relay working time, which is equal to $0.208 \mathrm{~s}$. With the faster working protection time, the value of heat energy produced is also smaller. The incident energy produced is $2.59 \mathrm{cal} / \mathrm{cm} 2$ to $1.48 \mathrm{cal} / \mathrm{cm} 2$

Keywords: Switchgear, protection relay, incident energy

\section{BAB 1 PENDAHULUAN}

\subsection{Latar Belakang}

Tuntutanakan ketersediaan energi listrik pada saat ini sangat tinggi. Hal ini membuat bekerja pada peralatan listrik aktif merupakan sebuah keharusan untuk memastikan kontinuitas dari ketersediaan energi listrik.Pekerjaan pada listrik aktif dilakukan pada kondisi sistem bekerja secara normal atau bertegangan.

Resiko saat bekerja pada listrik aktif selain kemungkinan adanya tegangan sentuh adalahkemungkinan adanya pelepasan energi akibat dari adanya hubung singkat (short circuit).Energi ini berlangsung terus menerus hingga peralatan proteksi bekerja.

Pada tahun 2016, di salah satu daerah operasi PT. Chevron Pasific Indonesia (CPI) terjadi kejadian di mana adanya short circuit yang menyebabkanterjadi busur api pada switchgear. Kejadian itu menyebabkan terjadi nya insiden bagi pekerja dan kerusakan pada peralatan yang ada pada switchgear sehingga water injection pump tidak dapat running.Salah satu penyebab terjadi nya kerusakan yang meluas di karenakan masih lambatnya rele proteksi bekerja sehingga dampak kerusakan terlalu besar.

\subsection{Tujuan Pembahasan}

Tujuan penulisan tugas akhir ini adalah untuk :

a. Mengevaluasi nilai setting rele over current

b. Menganalisa energi panas pada switchgear di Bekasap

\subsection{Manfaat Penulisan}

Manfaat dari penelitian ini yaitu sebagai referensi untuk mengevaluasi setting rele proteksi 
sehingga dapat bekerja lebih cepat dan mengurangi besarnya energi insiden akibat arc flash.

\subsection{Ruang Lingkup dan Batasan}

Pembahasan tugas akhir ini di fokuskan pada :

a. Sistem proteksi yang di evaluasi adalah pada rele over current.

b. Metoda yang dipakai dalam perhitungan analisis arc flash ini adalah dengan menggunakan standar IEEE 1584.

c. Program aplikasi yang di gunakan adalah Electrical Transient Analyzer Program (ETAP) untuk simulasi dan matchcad untuk validasi.

\section{BAB 2 TINJAUAN PUSTAKA}

\subsection{Hubung Singkat (Short Circuit)}

Arus hubung singkat tiga fasa terjadi ketika konduktor dalam sistem tenaga listrik tiga fasa terhubung singkat.Dalam prakteknya, hubung singkat tiga fasa jarangterjadi.Hubung singkat yang umum terjadi adalah satu fasa ke tanah dan antar fasa. Meski demikian, hubung singkat tiga fasa dipilih sebagai acuan karena nilainya paling besar dibanding dengan jenis hubung singkat yang lain[1]. Arus hubung singkat tiga fasa impedansi rendah (umum disebut bolted faulted current, $I_{b f}$ ) dinyatakan dalam persamaan berikut [2] :

$\mathrm{I}_{\mathrm{bf}}=\frac{\mathrm{E}}{Z_{s}}$

Keterangan :

$E=\mathrm{RMS}$ driving voltage

$Z_{s}=$ Impedansi konduktor sampai ke titik gangguan

\subsection{Perhitungan Arus Hubung Singkat}

Perhitungan arus gangguan dapat dilakukan dengan setiap reaktansi yang diekspresikan dalam ohm, sejumlah aturan harus diperhatikan seperti rating mesin dan perubahan tegangan sistem karena transformer.Metode perhitungan biasanya jauh lebih mudah jika reaktansi dinyatakan dalam persentase atau per satuan reaktansi.

Metode perhitungan sederhana lainnya adalah menggunakan sistem yang terukur (MVA) untuk perhitungan. Metode ini umumnya dikenal sebagai MVA metode [3].

Langkah perhitungan hubung singkat dengan metode per unit adalah [3] :

a. Tentukan basekVA yang akan di gunakan $\left(\mathrm{S}_{\text {base }}\right)$

b. Hitung nilai reaktansi dalam nilai per unit (pu) mengacu pada basekVA yang di pilih.

$$
\mathrm{Z}_{\text {base grid }}=\frac{\left(\mathrm{V}_{\text {base grid }}\right)^{2}}{\mathrm{~S}_{\text {base grid }}}(2.2)
$$

c. Sederhanakan rangkaian dengan menghitung semua reaktansi yang terlibat. d. Hitung arus base pada titik gangguan sesuai dengan kVA yang telah di pilih

$$
\mathrm{I}_{\text {base }}=\frac{\mathrm{S}_{\text {base grid }}}{\sqrt{3} \mathrm{v}_{\text {base grid }}}
$$

e. Hitung arus hubung singkat per unit tegangan sistem di bagi dengan impedansi total per unit

$$
\mathrm{I}_{\mathrm{bf} p u}=\frac{\mathrm{E}}{\text { Ztotal }}
$$

f. Hitung besarnya arus hubung singkat dengan mengalikan arus per unit dengan arus base

$$
\mathrm{I}_{\mathrm{bf}}=\mathrm{I}_{\mathrm{bf} \mathrm{pu}} \times \mathrm{I}_{\text {base }}
$$

\subsection{Energi Insiden}

\subsubsection{Pengertian Energi Insiden}

Energi insiden (incident energy)adalah energi yang terpapar ke pekerja pada jarak kerja tertentu saat terjadi hubung singkat busur. Energi ini adalah fungsi dari besar arus busur, durasi, jarak antar konduktor, jarak kerja dengan konduktor aktif dan jenis peralatan lisrik yang dikerjakan. Perhitungan energi insiden dibagi dalam dua kategori, yaitu untuk sistem bertegangan di bawah atau sama dengan $15 \mathrm{kV}$ dan di atas $15 \mathrm{kV}$.

\section{A. Perhitungan Energi Insiden (Tegangan $\leq$ $15 \mathrm{kV}$ )}

Energi insiden ternormalisasi adalah energi insiden dengan kondisi yang telah ditetapkan sebelumnya, yaitu durasi arus busur 0,2 detik dan jarak kerja 6,1 cm (2,4 inch), berdasarkan rumus[2]:

$\log E_{n}=K_{1}+K_{2}+1.081 \log I_{a}+0.0011 G(2.6)$

Keterangan :

$\mathrm{En}=$ Energi insiden ternormalisasi $(\mathrm{J} / \mathrm{cm} 2)$

$\mathrm{K} 1=-0.792$ untuk konfigurasi terbuka

-0.555 untuk konfigurasi kotak / tertutup

$\mathrm{K} 2$ = 0 untuk ungrounded

-0.113 untuk sistem kelistrikan yang dibumikan

$\mathrm{I}_{\mathrm{a}}=\operatorname{Arus}$ busur $(\mathrm{kA})$

$\mathrm{G}=$ Jarak antar konduktor (mm), lihat Tabel 2.1

Maka perhitungan energi insiden berdasarkan rumus [2]adalah :

$$
\mathrm{E}=4.184 \mathrm{C}_{\mathrm{f}} \mathrm{E}_{\mathrm{n}}\left(\frac{\mathrm{t}}{0.2}\right)\left(\frac{610^{\mathrm{x}}}{\mathrm{D}^{\mathrm{x}}}\right)(2.7)
$$

\section{Keterangan :}

$\begin{array}{ll}\text { En } & =\text { Energi insiden }(\mathrm{J} / \mathrm{cm} 2) \\ \mathrm{Cf} & =\text { Kalkulasi faktor } \\ & 1 \text { untuk } \mathrm{V}>1 \mathrm{kV} \\ & 0 \text { untuk } \mathrm{V}<1 \mathrm{kV} \\ \mathrm{En} & =\text { Energi insiden ternormalisasi }(\mathrm{J} / \mathrm{cm} 2) \\ \mathrm{t} & =\text { Arching time }(\mathrm{s}) \\ \mathrm{D} & =\text { Jarak antar pekerja dengan konduktor, } \\ & \text { lihat Tabel } 2.3\end{array}$


$\mathrm{X}$

= Koefisien jarak antar konduktor, lihat Tabel 2.2

Tabel 2.1 Koefisien jarak antar konduktor (x)

\begin{tabular}{|c|l|l|l|}
\hline $\begin{array}{c}\text { Sistem } \\
\text { Tegangan } \\
(\mathrm{kV})\end{array}$ & $\begin{array}{l}\text { Jenis } \\
\text { Peralatan } \\
\text { Listrik }\end{array}$ & $\mathrm{G}(\mathrm{mm})$ & $\begin{array}{l}\text { Koefisien } \\
\text { jarak } \\
(\mathrm{x})\end{array}$ \\
\hline \multirow{5}{*}{$0.280-1$} & Open air & $10-40$ & 2 \\
\cline { 2 - 4 } & Switchgear & 32 & 1,473 \\
\cline { 2 - 4 } & $\begin{array}{l}\text { MCC and } \\
\text { panels }\end{array}$ & 25 & 1,641 \\
\cline { 2 - 4 } & Cable & 13 & 2 \\
\hline \multirow{5}{*}{$1-5 \mathrm{kV}$} & Open air & 102 & 2 \\
\cline { 2 - 4 } & Switchgear & $13-102$ & 0,973 \\
\cline { 2 - 4 } & Cable & 13 & 2 \\
\hline \multirow{5}{*}{$5-15 \mathrm{kV}$} & Open air & $13-153$ & 2 \\
\cline { 2 - 4 } & Switchgear & 153 & 0,973 \\
\cline { 2 - 4 } & Cable & 13 & 2 \\
\hline
\end{tabular}

Tabel 2.2 Tipikal jarak kerja

\begin{tabular}{|l|c|}
\hline \multicolumn{1}{|c|}{ Classes of equipment } & $\begin{array}{c}\text { Typical working } \\
\text { distance }(\mathrm{mm})\end{array}$ \\
\hline $15 \mathrm{kV}$ Switchgear & 910 \\
\hline $5 \mathrm{kV}$ Switchgear & 910 \\
\hline Low Voltage Switchgear & 610 \\
\hline $\begin{array}{l}\text { Low Voltage MCC and panel } \\
\text { boards }\end{array}$ & 455 \\
\hline Cable & 455 \\
\hline Others & $\begin{array}{c}\text { To be determined in } \\
\text { field }\end{array}$ \\
\hline
\end{tabular}

\section{B. Perhitungan Energi Insiden (Tegangan $\geq$} $15 \mathrm{kV}$ )

Untuk perhitungan energi insiden dengan tegangan $\geq 15 \mathrm{kV}$ dapat dihitung menggunakan persamaan berikut [2]:

$\mathrm{E}=2.142 \times 10^{6} \mathrm{~V} \mathrm{I}_{\mathrm{bf}}\left(\frac{\mathrm{t}}{\mathrm{D}^{2}}\right)$

Keterangan :

$\mathrm{E}=$ Energi insiden $(\mathrm{J} / \mathrm{cm} 2)$

$\mathrm{V}=$ Tegangan sistem $(\mathrm{kV})$

$\mathrm{t}=$ Durasi arus busur ( $\mathrm{s}$ )

$\mathrm{D}=$ Jarak kerja pekerja dengan konduktor $(\mathrm{mm})$

Ibf =Arus hubung singkat / Bolted faulted current (kA)

\subsection{Sistem Proteksi}

Proteksi sistem tenaga listrik adalah sistem proteksi yang dipasang pada peralatan listrik suatu sistem tenaga listrik, misalnya generator, transformator, jaringan dan lain-lain, terhadap kondisi abnormal operasi sistem itu sendiri. Kondisi abnormal itu dapat berupa antara lain : hubung singkat, tegangan lebih, beban lebih, frekuensi sistem rendah dan lain-lain.

\subsubsection{Syarat Umum Rele Proteksi}

Ada beberapa persyaratan yang sangat perlu diperhatikan dalam suatu perencanaan sistem proteksi yang efektif yaitu[4]:

\section{a. Selektivitas}

Yang di maksud dengan selektif di sini adalah kecermatan pemilihan dalam mengadakan pengamanan, di mana hal ini menyangkut koordinasi pengamanan dari sistem secara keseluruhan. Untuk mendapatkan kehandalan yang tinggi, maka rele pengaman harus mempunyai kemampuan selektif yang baik

\section{b. Stabilitas}

Sifat yang tetap inoperatif apabila gangguangangguan terjadi diluar daerah yang melindungi (gangguan luar).

\section{c. Kecepatan Operasi}

Rele harus cepat bereaksi / bekerja bila sistem mengalami gangguan atau kerja abnormal. Kecepatan bereaksi dari rele adalah saat rele muIai merasakan adanya gangguan sampai dengan pelaksanaan pelepasan circuit breaker (CB) karena komando dari rele tersebut. Waktu bereaksi ini harus diusahakan secepat mungkin sehingga dapat menghindari kerusakan pada alat serta membatasi daerah yang mengalami gangguan / kerja abnormal. Mengingat suatu sistem tenaga mempunyai batasbatas stabilitas serta kadang-kadang gangguan sistem bersifat sementara, maka rele yang semestinya bereaksi dengan cepat kerjanya perlu di perlambat (time delay).

\section{d. Sensitivitas (kepekaan)}

Rele harus dapat bekerja dengan kepekaan yang tinggi, artinya harus cukup sensitif terhadap gangguan di daerahnya meskipun gangguan tersebut minimum, selanjutnya memberikan jawaban atau response

\section{e. Pertimbangan ekonomis}

Satu hal yang harus diperhatikan sebagai persyaratan rele pengaman adalah masalah harga atau biaya. Rele tidak akan diaplikasikan dalam sistem tenaga listrik, jika harganya sangat mahal. Persyaratan reliabilitas, sensitivitas, selektivitas dan kecepatan kerja rele hendaknya tidak menyebabkan harga rele tersebut menjadi mahal

\section{f. Realiability (kehandalan)}

Pada kondisi normal (tidak ada gangguan) rele tidak bekerja. Jika terjadi gangguan maka rele tidak boleh gagal bekerja dalam mengatasi gangguan. Kegagalan kerja rele dapat mengakibatkan alat yang di amankan rusak berat 
atau gangguannya meluas sehingga daerah yang mengalami pemadaman semakin luas

\subsection{Rele Arus Lebih (Over Current)}

\subsubsection{Pengertian Rele Arus Lebih}

Proteksi arus lebih adalah proteksi terhadap perubahan parameter arus yang sangatbesar dan terjadi pada waktu yang sangat cepat, yang disebabkan oleh hubung singkat. Pada proteksi arus lebih ini, rele akanpick up jika besar arus melebihi nilai setting. Elemen dasar dari proteksi ini adalah rele arus.Proteksi arus lebih meliputi proteksi terhadap gangguan hubung singkat yang dapat berupa hubung singkat fasa-fasa, satu fasa ketanah, dan hubung singkat antar fasa [5].

\begin{tabular}{|c|c|c|}
\hline Brand & \multicolumn{2}{|l|}{ GE Multilin } \\
\hline Model & \multicolumn{2}{|l|}{ SR 745} \\
\hline \multicolumn{3}{|l|}{ CT } \\
\hline Phase & \multicolumn{2}{|l|}{$800 / 5$} \\
\hline \multirow[t]{2}{*}{ GND } & \multicolumn{2}{|l|}{$200 / 5$} \\
\hline & Range & Setting \\
\hline \multirow[t]{3}{*}{ Phase TOC } & Extremely Inverse & \\
\hline & $\begin{array}{l}\text { Pickup ( Tap ) } 0.05- \\
20 \text { x CT Sec }\end{array}$ & 0.78 \\
\hline & Time dial & 2.4 \\
\hline
\end{tabular}

\subsubsection{Dasar Setting Rele}

Untuk penentuan setting rele overcurrent adalah [6]:

1. Menghitung besar nya arus minimal $\left(\mathrm{I}_{\mathrm{n}}\right)$

$$
\mathrm{I}_{\mathrm{n}}=\frac{\mathrm{kVA}}{\sqrt{3} \times \mathrm{kV}}
$$

2. Menghitung besar nya arus pada CT :

$$
\mathrm{I}_{\mathrm{s}}=\frac{\mathrm{K}_{\mathrm{fk}}}{\mathrm{K}_{\mathrm{d}}} \times \mathrm{I}_{\mathrm{n}}(2.13)
$$

3. Menentukan TMS (time multiplier setting)

$$
\mathrm{TMS}=\frac{\Delta \mathrm{t} \times \frac{\mathrm{Isc}}{\mathrm{Is}}-1}{5.4}
$$

4. Menetukan time dial setting $\left(\mathrm{t}_{\mathrm{d}}\right)$

$$
t_{d}=\frac{A}{\left(\frac{I}{I s}\right)^{P}-1} \times \frac{M}{10}
$$

Keterangan :

$\mathrm{T} \quad=$ waktu kerja rele

$\mathrm{I}_{\mathrm{s}} \quad=$ nilai setting arus rele

I $\quad=$ nilai arus aktual

TMS =time multiplier setting

A dan $\mathrm{P}=$ konstanta rele berdasarkan jenis kurva arus lebih

A dan $P$ berdasarkan Tabel 2.4 [7]
Tabel 2.1 Konstanta Rele arus lebih

\begin{tabular}{|l|l|l|}
\hline IEEE curve shape & A & P \\
\hline Extremely Inverse & 80 & 2,0000 \\
\hline Very Inverse & 13.5 & 2,0000 \\
\hline Moderately Inverse & 0.14 & 0,0200 \\
\hline
\end{tabular}

\section{BAB 3 METODE PENELITIAN}

\subsection{Data Sistem Kelistrikan}

Pada analisis arc flash ini mengambil data sistem tenaga listrik pada sistem $4.160 \mathrm{~V}$ bekasap area di PT. Chevron Pacific Indonesia. Daerah bekasap area yang akan di lakukan perhitungan adalah pada area Bekasap Gathering Station (GS). Tegangan dari 13,2 kV diturunkan menjadi $4.160 \mathrm{~V}$ yang di distribusikan pada water injection pump

Sistem kelistrikan pada area Bekasap GSmenggunakan rele over current untuk sistem proteksi nya.

Sistem proteksi padaswitchgear di Bekasap GS menggunakan jenis rele dengan brand GE Multilin 750 pada sisi primary dan secondary nya. Untuk data sistem proteksi pada switchgear yang ada di Bekasap GS

\section{BAB 4PEMBAHASAN}

Perhitungan yang dilakukan pada pembahasan ini berdasarkan pengumpulan data yang telah dilakukan selama observasi.

\subsection{Perhitungan Existing}

\subsubsection{Perhitungan $I_{b f}$}

1. Menentukan besarnya base kVA yang akan di gunakan :

$$
\begin{array}{ll}
\mathrm{S}_{\text {base }} & =100 \mathrm{MVA} \\
\mathrm{S}_{\text {trafo }} & =3 \mathrm{MVA} \\
\mathrm{V}_{\text {base grid }} & =13,2 \mathrm{kV} \\
\mathrm{V}_{\text {base trafo }} & =4,16 \mathrm{kV}
\end{array}
$$

2. Besarnya reaktansi dalam nilai per unit (pu) mengacu pada base kVA berdasarkan persamaan 2.2 :

$$
\begin{aligned}
\mathrm{Z}_{\text {base grid }} & =\frac{\left(\mathrm{V}_{\text {base grid }}\right)^{2}}{\mathrm{~S}_{\text {base grid }}} \\
& =\frac{(13,2 \mathrm{kV})^{2}}{100 \mathrm{MVA}} \\
& =1,7424 \mathrm{Ohm} \\
\mathrm{Z}_{\text {base trafo }} & =\frac{\left(\mathrm{V}_{\text {base trafo }}\right)^{2}}{\mathrm{~S}_{\text {base }}} \\
& =\frac{(4,16 \mathrm{kV})^{2}}{100 \mathrm{MVA}} \\
& =0,173056 \mathrm{Ohm}
\end{aligned}
$$


3. Besarnya arus base pada titik gangguan sesuai dengan kVA berdasarkan persamaan 2.3 :

$$
\begin{aligned}
\mathrm{I}_{\text {base grid }} & =\frac{\mathrm{S}_{\text {base grid }}}{\sqrt{3} \mathrm{~V}_{\text {base grid }}} \\
& =\frac{100 \mathrm{MVA}}{\sqrt{3} 13,2 \mathrm{kV}} \\
& =4,37386 \mathrm{kA} \\
\mathrm{I}_{\text {base trafo }} & =\frac{S_{\text {base trafo }}}{\sqrt{3} \mathrm{~V}_{\text {base trafo }}} \\
& =\frac{100 \mathrm{MVA}}{\sqrt{3} 4,16 \mathrm{kV}} \\
& =13,87861 \mathrm{kA}
\end{aligned}
$$

4. Besarnya impedansi setiap komponen per unit (pu):

a. $\quad$ Grid

$$
\begin{aligned}
& \mathrm{V}=13,8 \mathrm{kV} \\
& \mathrm{X}_{\mathrm{pu}}=0,4841 \mathrm{pu} \\
& \mathrm{R}_{\mathrm{pu}}=0,0420 \mathrm{pu}
\end{aligned}
$$

b. Cable 1

$$
\begin{aligned}
\mathrm{V} & =13,8 \mathrm{kV} \\
\mathrm{X} & =0,00721 \mathrm{Ohm} \\
\mathrm{R} & =0,02017 \mathrm{Ohm} \\
\mathrm{X}_{\mathrm{pu}} & =\frac{\mathrm{X}}{\mathrm{Z}_{\text {base grid }}} \\
& =\frac{0,00721 \mathrm{Ohm}}{1,7424 \mathrm{Ohm}} \\
& =0,004138 \mathrm{pu} \\
\mathrm{R}_{\mathrm{pu}}= & \mathrm{R} \\
\mathrm{Z}_{\text {base grid }} & 0,02017 \mathrm{Ohm} \\
= & \frac{0,7424 \mathrm{Ohm}}{} \\
= & 0,011576 \mathrm{pu}
\end{aligned}
$$

c. Cable 2

$$
\begin{aligned}
\mathrm{V} & =13,8 \mathrm{kV} \\
\mathrm{X} & =0,00721 \mathrm{Ohm} \\
\mathrm{R} & =0,02017 \mathrm{Ohm} \\
\mathrm{X}_{\text {pu }} & =\frac{\mathrm{X}}{\mathrm{Z}_{\text {base grid }}} \\
& =\frac{0,00721 \mathrm{Ohm}}{1,7424 \mathrm{Ohm}} \\
& =0,004138 \mathrm{pu} \\
\mathrm{R}_{\text {pu }} & =\frac{\mathrm{R}}{\mathrm{Z}_{\text {base grid }}}
\end{aligned}
$$

$$
\begin{aligned}
& =\frac{0,02017 \mathrm{Ohm}}{1,7424 \mathrm{Ohm}} \\
& =0,011576 \mathrm{pu}
\end{aligned}
$$

d. Trafo

$$
\begin{aligned}
\text { Tap } & =0,975 \\
X_{1} & =0,06472 \mathrm{Ohm} \\
\mathrm{R}_{1} & =0,00607 \mathrm{Ohm} \\
\mathrm{X}_{\mathrm{pu}} & =\frac{\mathrm{S}_{\text {base grid }}}{\mathrm{Z}_{\text {base trafo }}} \times\left(\mathrm{X}_{1} \times \text { tap }\right) \\
& =\frac{100 \mathrm{MVA}}{3 \mathrm{MVA}} \times(0,06472 \mathrm{Ohm} \times 0,975) \\
& =2,0134 \mathrm{pu} \\
\mathrm{R}_{\mathrm{pu}} & =\frac{\mathrm{S}_{\text {base grid }}}{\mathrm{Z}_{\text {base trafo }}} \times\left(\mathrm{R}_{1} \times \text { tap }\right) \\
& =\frac{100 \mathrm{MVA}}{3 \mathrm{MVA}} \times(0,0607 \mathrm{Ohm} \times 0,975) \\
& =0,197275 \mathrm{pu}
\end{aligned}
$$

e. Cable 3

$$
\begin{aligned}
\mathrm{V} & =4,16 \mathrm{kV} \\
\mathrm{X} & =0,00618 \mathrm{Ohm} \\
\mathrm{R} & =0,00851 \mathrm{Ohm} \\
\mathrm{X}_{\mathrm{pu}} & =\frac{\mathrm{X}}{\mathrm{Z}_{\text {base trafo }}} \\
& =\frac{0,00618 \mathrm{Ohm}}{0,173056 \mathrm{Ohm}} \\
& =0,035711 \mathrm{pu} \\
\mathrm{R}_{\text {pu }} & =\frac{\mathrm{R}}{\mathrm{Z}_{\text {base trafo }}} \\
& =\frac{0,00851 \mathrm{Ohm}}{0,173056 \mathrm{Ohm}} \\
& =0,049175 \mathrm{pu}
\end{aligned}
$$

5. Besarnya Impedansi total pada sistem tenaga listrik adalah :

$$
\begin{aligned}
\mathrm{X}_{\mathrm{pu}}= & \mathrm{X}_{\mathrm{pu}} \text { grid }+\mathrm{X}_{\mathrm{pu}} \text { cable } 1+\mathrm{X}_{\mathrm{pu}} \text { cable } 2+ \\
& \mathrm{X}_{\mathrm{pu}} \text { trafo }+\mathrm{X}_{\mathrm{pu}} \text { cable } 3 \\
= & 0,4841 \mathrm{pu}+0,004138 \mathrm{pu}+0,004138 \mathrm{pu} \\
& +2,1034 \mathrm{pu}+0,035711 \mathrm{pu} \\
= & 2,6315 \mathrm{pu} \\
\mathrm{R}_{\mathrm{pu}}= & \mathrm{R}_{\mathrm{pu}} \text { grid }+\mathrm{R}_{\mathrm{pu}} \text { cable } 1+\mathrm{R}_{\mathrm{pu}} \text { cable } 2+ \\
& \mathrm{R}_{\mathrm{pu}} \text { trafo }+\mathrm{R}_{\mathrm{pu}} \text { cable } 3 \\
= & 0,420 \mathrm{pu}+0,011576 \mathrm{pu}+0,011576 \mathrm{pu}+ \\
& 0,197275 \mathrm{pu}+0,049175 \mathrm{pu}
\end{aligned}
$$




$$
\begin{aligned}
& =0,3116 \mathrm{pu} \\
\mathrm{Z}_{\text {total }}= & \mathrm{R}+\mathrm{jX} \\
& =0,3116+\mathrm{j} 2,6315 \\
& =2,6498 \mathrm{pu}
\end{aligned}
$$

6. Besarnya arus bolted fault ( $\left.\mathrm{I}_{\mathrm{bf}}\right)$ per unit berdasarkan persamaan 2.4 :

$$
\mathrm{I}_{\mathrm{bf} \mathrm{pu}}=\frac{\mathrm{E}}{\text { Ztotal }}
$$

$$
\begin{aligned}
& =\frac{1}{2,6498} \\
& =0,377377 \mathrm{pu}
\end{aligned}
$$

7. Besarnya arus bolted fault ( $\left.\mathrm{I}_{\mathrm{bf}}\right)$ berdasarkan persamaan 2.5 :

$$
\begin{gathered}
\mathrm{I}_{\mathrm{bf}}=\mathrm{I}_{\mathrm{bf} \text { pu }} \times \mathrm{I}_{\text {base trafo }} \\
=0,377377 \mathrm{pu} \times 13,87861 \mathrm{kA} \\
=5.2 \mathrm{kA}
\end{gathered}
$$

\subsubsection{Perhitungan Energi Insiden}

Berdasarkan pada persamaan 2.7, di dapat hasil perhitungan energi insiden sebagai berikut :

$$
\begin{aligned}
& \quad E=4.184 C_{\mathrm{f}} \mathrm{E}_{\mathrm{n}}\left(\frac{\mathrm{t}}{0.2}\right)\left(\frac{610^{\mathrm{x}}}{\mathrm{D}^{\mathrm{x}}}\right) \\
& =4,184 \times 1 \times 2,102\left(\frac{0,366}{0,2}\right)\left(\frac{610^{0,973}}{910^{0.973}}\right) \\
& =(8,794)(1,83)(0,6776) \\
& =10,904 \mathrm{~J} / \mathrm{cm}^{2} \\
& =2,6 \mathrm{~J} / \mathrm{cm}^{2}
\end{aligned}
$$

\subsection{Kurva TCC (existing)}

Dari hasil perancangan pada ETAP setelah di masukkan nilai setting pada rele over current baik pada sisi secondary maupun primary maka di dapat kurva TCC seperti pada Gambar 4.1 :

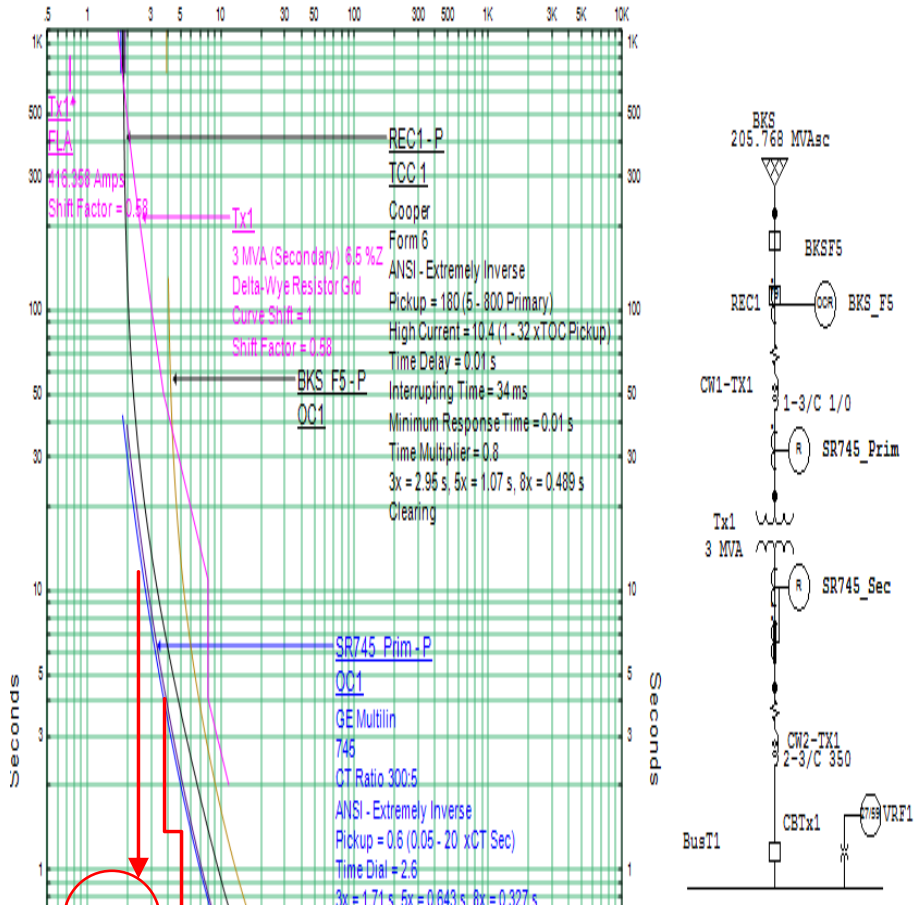

b

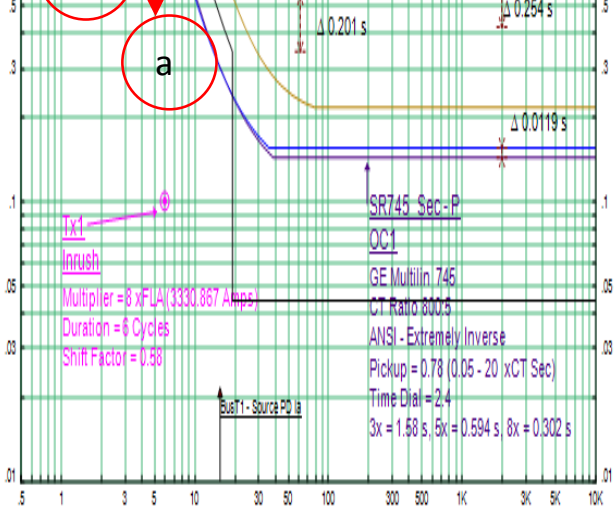

Amps X 100 BWT11 (Nom. $k V=13.4$, Plot Ref. $k V=13.4$ )

Gambar 4.1 Kurva TCC Existing

Dari Gambar 4.1ada 2 hal yang dapat di evaluasi, yaitu :

a. Nilai dari OCR secondary masih terlalu jauh dari besarnya arus gangguan yang akan terjadi. Dari kurva tersebut nilai dari OCR CR 745 dapat di setting sehingga bekerja lebih cepat dan dapat mengurangi besarnya energy incident yang akan terjadi.

b. Rele OC SR 745 primary juga dapat di setting ulang agar saat terjadi gangguan tidak ada delay yang terlalu lama dengan rele OCR SR 745 secondary. 


\subsection{Perhitungan Setting Rele}

\subsubsection{Rele Secondary}

\section{A. Nilai Arus Nominal $\left(\mathbf{I}_{\mathbf{n}}\right)$}

Berdasarkan persamaan 2.12 di dapat kan perhitungan sebagai berikut :

$$
\begin{aligned}
& I_{n}=\frac{k V A}{\sqrt{3} \times k V} \\
& I_{n}=3000 / \sqrt{3} \times 4,16 \mathrm{kV} \\
& =416,35 \mathrm{Amp}
\end{aligned}
$$

\section{B. Arus Pada CT}

Berdasarkan persamaan 2.13 di dapat kan perhitungan sebagai berikut :

$$
\begin{aligned}
& I_{s}=\frac{K_{\text {fk }}}{K_{d}} \times I_{n} \\
& I_{s}=1,2 / 1 \times 416,35 \mathrm{Amp} \\
& =499,63 \mathrm{Amp}
\end{aligned}
$$

\section{Menentukan Time Multiplier Setting}

Berdasarkan persamaan 2.14 di dapat kan perhitungan sebagai berikut :

$$
\begin{aligned}
\mathrm{TMS}=\frac{\Delta \mathrm{t} \times \frac{\mathrm{Isc}}{\mathrm{Is}}-1}{5.4} \\
\mathrm{TMS}=\frac{\left(0,7 \times\left(\frac{5.203 \mathrm{Amp}}{499,63 \mathrm{Amp}}-1\right)\right.}{5.4} \\
=1,2 \mathrm{~s}
\end{aligned}
$$

\section{Time Delay Setting Rele}

Berdasarkan persamaan 2.15, perhitungan time dial dengan tipe kurva extremely inverse time delay maka di dapat kan perhitungan sebagai berikut :

$$
\begin{gathered}
t_{d}=\frac{80}{\left(\frac{I}{I s}\right)^{2}-1} \times \frac{\text { TMS }}{10} \\
t_{d}=\frac{80}{\left(\frac{1627 \text { Amp }}{499,63 \text { Amp }}\right)^{2}-1} \times \frac{1,2}{10} \\
t_{d}=1,02 \mathrm{~s}
\end{gathered}
$$

\subsubsection{Rele Primary}

\section{A. Nilai Arus Nominal $\left(\mathbf{I}_{\mathbf{n}}\right)$}

Berdasarkan persamaan 2.12 di dapat kan perhitungan sebagai berikut :

$$
\mathrm{I}_{\mathrm{n}}=\frac{\mathrm{kVA}}{\sqrt{3} \times \mathrm{kV}} I_{\mathrm{n}}
$$

$$
\begin{aligned}
& =\frac{3000}{\sqrt{ } 3 \times 13,8 \mathrm{kV}} \\
& =125,5 \mathrm{Amp}
\end{aligned}
$$

\section{B. Arus Pada CT}

Berdasarkan persamaan 2.13 di dapat kan perhitungan sebagai berikut :

$$
\begin{aligned}
I_{\mathrm{s}}=\frac{\mathrm{K}_{\mathrm{fk}}}{\mathrm{K}_{\mathrm{d}}} \times \mathrm{I}_{\mathrm{n}} \\
\mathrm{I}_{\mathrm{S}}=\frac{1.2}{1 \times 125,5 \mathrm{Amp}} \\
=150,6 \mathrm{Amp}
\end{aligned}
$$

\section{Menentukan Time Multiplier Setting}

Berdasarkan persamaan 2.14 di dapat kan perhitungan sebagai berikut :

$$
\begin{aligned}
\mathrm{TMS} & =\frac{\Delta \mathrm{t} \times \frac{\mathrm{Isc}}{\mathrm{Is}}-1}{5.4} \\
\mathrm{TMS} & =\left(\frac{0,7 \times\left(\frac{5.203 \mathrm{Amp}}{150,6 \mathrm{Amp}}-1\right)}{5.4}\right) \\
& =4,35 \mathrm{~s}
\end{aligned}
$$

\section{Time Delay Setting Rele}

Berdasarkan persamaan 2.15 , perhitungan time dial dengan tipe kurva extremely inverse time delay maka di dapat kan perhitungan sebagai berikut :

$$
\begin{gathered}
t_{d}=\frac{80}{\left(\frac{I}{I s}\right)^{2}-1} \times \frac{T M S}{10} \\
t_{d}=\frac{80}{\left(\frac{867 \text { Amp }}{150,6 \text { Amp }}\right)^{2}-1} \times \frac{4,35}{10} \\
t_{d}=1,08 \mathrm{~s}
\end{gathered}
$$

Dengan nilai setting SR 745 yang sekarang baik primary dan juga secondary di lakukan simulasi dengan ETAP dan di dapat kan hasil kurva TCC seperti pada Gambar 4.2. 


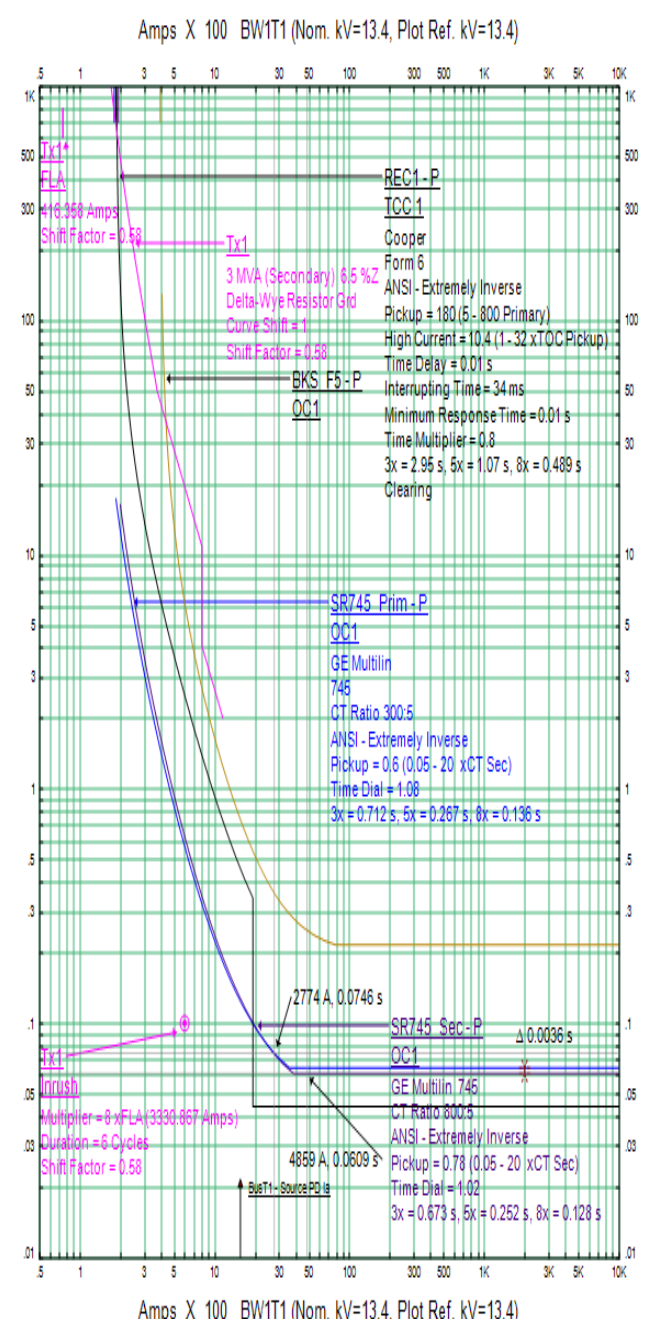

Gambar 4.2 Kurva TCC New

Pada Gambar 4.2 kurva TCC dari secondary maupun TCC primary lebih turun dari yang sebelumnya dan mendekati arus gangguan yang nantinya akan terjadi. Dengan lebih mendekati besar nya arus gangguan maka kerja rele OCR secondary nantinya akan lebih cepat dari sebelumnya dalam mengantisipasi besarnya gangguan yang akan terjadi pada bus T1 dan bus T2.

Pada Gambar 4.2 selisih waktu kerja antara OCRprimary dan OCRsecondary sangat kecil yaitu sebesar 0,0036 s. Jika OCR secondary gagal bekerja maka OCR primary akan langsung bekerja sehingga gangguan yang terjadi tidak meluas.

Dengan perubahan nilai setting pada OCR secondary, nilai arching time akan lebih cepat yaitu 0.208 s.Maka nilai energy incident sekarang berdasarkan persamaan 2.9 adalah :

$$
E=4,184 C_{f} E_{n}\left(\frac{t}{0,2}\right)\left(\frac{610^{x}}{D^{x}}\right)
$$

$$
\begin{aligned}
& =4,184 \times 1 \times 2,102\left(\frac{0,208}{0,2}\right)\left(\frac{610^{0,973}}{910^{0,973}}\right) \\
& =(8,974)(1,04)(0,6776) \\
& =6,197 \mathrm{~J} / \mathrm{cm}^{2} \\
& =1,48 \mathrm{cal} / \mathrm{cm}^{2}
\end{aligned}
$$

Perubahan pada setting OCR menyebabkan Fault Clearing Time (FCT) menjadi lebih cepat. Jika di bandingkan dengan kondisi yang sebelumnya dimana FCT nya yaitu sebesar $0,366 \mathrm{~s}$, di dapat nilai energi insiden yang masih tinggi yaitu sebesar 2,59 $\mathrm{cal} / \mathrm{cm}^{2}$.Pada kondisi yang sekarang nilai FCT nya lebih cepat yaitu sebesar 0,208s. Dengan semakin cepat nya nilai FCT membuat energi insiden yang di hasilkan juga menjadi lebih kecil yaitu sebesar 1,48

\begin{tabular}{|c|c|c|c|c|}
\hline No & Keterangan & & Existing & New \\
\hline \multirow[b]{2}{*}{1} & \multirow{2}{*}{$\begin{array}{l}\text { Time dial } \\
\text { (Td) }\end{array}$} & Primary & $2,6 \mathrm{~s}$ & $1,08 \mathrm{~s}$ \\
\hline & & Secondary & $2,4 \mathrm{~s}$ & $1,02 \mathrm{~s}$ \\
\hline 2 & $\begin{array}{l}\text { Fault } \\
\text { Clearing } \\
\text { Time }(F C T)\end{array}$ & & $0,306 \mathrm{~s}$ & $0,208 \mathrm{~s}$ \\
\hline 3 & $\begin{array}{l}\text { Energy } \\
\text { Incident(EI) }\end{array}$ & & $\begin{array}{c}2,59 \\
\mathrm{cal} / \mathrm{cm}^{2}\end{array}$ & $\begin{array}{c}1,48 \\
\mathrm{cal} / \mathrm{cm}^{2}\end{array}$ \\
\hline
\end{tabular}
$\mathrm{cal} / \mathrm{cm}^{2}$. Dengan begitu energi insiden yang di hasilkan mengalami penurunan sebesar $42,85 \%$. Perubahan dari hasil evaluasi seperti pada tabel 4.1

Tabel 4.1Tabel Evaluasi Setting OCR

\section{BAB 5 KESIMPULAN DAN SARAN 5.1 KESIMPULAN}

Hasil yang dapat disimpulkan pada evaluasi setting rele proteksi di switchgear Bekasap area PT. Chevron Pacific Indonesia adalah sebagai berikut :

a. Evaluasi setting di lakukan pada OCR primary dan OCR secondary Untuk OCR primary nilai settingtime dial yang sebelumnya 2,6 s menjadi 1,08 s sedangkan untuk OCR secondary dengan time dial 2,4 s menjadi $1,02 \mathrm{~s}$

b. Perubahan nilai setting membuat koordinasi antar rele OCR primary dan OCR secondary selisih $0,0036 \mathrm{~s}$.

c. Waktu kerja rele menjadi lebih cepat ketika terjadi gangguan pada bus T1 dan bus T2. Pada kondisi sebelum nya waktu dalam mengatasi gangguan adalah 0,366 s sekarang menjadi $0,208 \mathrm{~s}$.

d. Dengan waktu yang lebih cepat membuat energi panas yang di hasilkan juga semakin kecil. Energi panas yang dihasilkan sebelumnya adalah $2,59 \mathrm{cal} / \mathrm{cm}^{2}$ menjadi $1,48 \mathrm{cal} / \mathrm{cm}^{2}$.

\subsection{SARAN}

Berdasarkan dari hasil analisa penulis menyarankan perlu di lakukan analisa terhadap arc 
flash dan juga memastikan kembali koordinasi terhadap sistem proteksi yang ada di PT. Chevron Pasific Indonesia.

\section{DAFTAR PUSTAKA}

[1] IEEE 551, IEEE Recommended Practice for Calculating Short-Circuit Currents in Industrial and Commercial Power Systems. 2006.

[2] IEEE 1584, IEEE Guide for Performing Arc-Flash Hazard Calculations. 2002.

[3] R. . Garzon, "High voltage circuit breaker design and applications," in Current, 2nd ed., New york: MARCEL DEKKEIRN,C, 2002, pp. 29-29.

[4] J. L. Blackburn and T. J.Domin, Protective Relay Principles and Applications, Third., vol. 4. London: CRC Press, 1999.

[5] M. T. Alawiy, "Proteksi sistem tenaga listrik," no. 1, 2006.

[6] H. Martha Yudha, Rele proteksi: Prinsip dan Aplikasi. Palembang: Jurusan Teknik Elektro Sriwijaya, 2008.

[7] G. I. S. Ere (2009), 745 Transformer Protection System Instruction Manual. Kanad: GE Multilin Incorporated. 